\title{
IMPROVING COMMUNITY AWARENESS FOR A CLEAN AND HEALTHY LIFE TO PREVENT THE SPREAD OF COVID 19 IN TANAH KALI KEDINDING, KENJERAN, SURABAYA
}

\author{
Taty Alfiah*, Rachmanu Eko Handriyono, dan Talent Nia Pramestyawati \\ Department of Environmental Engineering, Institut Teknologi Adhi Tama Surabaya, Indonesia
}

\begin{abstract}
High population density in urban areas is a challenge in preventing the spread of Covid 19. High population density encourages the occurrence of crowds in public facilities, which has a great potential for the spread of the Covid 19 virus. People's awareness to live clean and healthy is an individual's role in realizing personal health, family and the environment. One of the healthy behaviors is the habit of washing hands with soap, which is an effort to prevent the spread of Covid 19. However, everyone's awareness is different, influenced by their socio-economic background. Education on clean and healthy living needs to be carried out continuously, therefore, ITATS Environmental Engineering Department, conducts community service activities in the form of education on clean and healthy living in Tanah Kali Kedinding Village, Kenjeran, Surabaya. Activities of this community service include assisstanship and facilities donation. The result shows that Covid 19 spreading was lowering after the event. The community awareness on cleaner and healthier living is improved.
\end{abstract}

Keywords: Covid 19, hand washing, Kenjeran,

\section{Introduction}

In early 2021, the Indonesian government began to carry out vaccinations gradually to prevent an increase in new cases of Covid 19. New cases of Covid-19 are still increasing in various parts of Indonesia. The Indonesian population who live in urban areas is $52.9 \%$, this causes a high level of population density in urban areas. High population density makes it difficult to maintain social distancing, facilitates crowds, thereby facilitating the spread of the Covid 19 virus. The habit of washing hands with soap using running water is an effort to prevent the addition of new cases of Covid 19. Education on the habit of

\footnotetext{
${ }^{*}$ Corresponding Author:

E-mail: taty09@itats.ac.id

Received: 2 February 2021

Revised: 23 February 2021

Accepted: 23 February 2021
}

washing hands with soap needs to be carried out continuously (Purnama \& Susanna, 2020) (Proverbs, 2020).

PHBS (Clean and Healthy Living Behavior) is behavior that is carried out consciously as a result of learning to be healthy independently and to take an active role in realizing public health is the core of. PHBS can be implemented in household environments, health facilities, educational institutions, workplaces and public places. Using clean water and washing hands with soap are two out of ten PHBS behaviors that can be carried out in the household environment by every family member. These two behaviors are closely related to the government's appeal to prevent the spread of Covid 19 in society, namely wearing masks, maintaining distance and washing hands using clean water and soap (Indonesian Ministry of Health, 2011). 
Data on Covid 19 cases from April 2020 to July 2020 there was an increase in the number of Covid 19 cases in Kenjeran District, Surabaya City and the highest was in the Tanah Kali Kedinding Village area. Kenjeran District is located in the northern part of Surabaya City, consisting of 4 villages, namely Tanah Kali Kedinding Village, Sidotopo Wetan Village, Bulak Banteng Village and Tambak Wedi Village.

Students as the younger generation who will become agents of change in the future, apart from learning, they must also have concern for the surrounding community. As a student of the ITATS Environmental Engineering Department, who already has knowledge related to the provision of clean water and public health, and then conducts community service activities in the form of education on clean and healthy living related to an effort to prevent the spread of Covid 19 in Tanah Kali Kedinding Village, Kenjeran, Surabaya (Iriani et al., 2020).

The activity includes assisstanship on behavior changing of the community in dealing with the Covid 19 pandemi. This community service was also conducted to investigate its effect to Covid 19 spread.

\section{Methodology \\ Method}

This study was conducted using a qualitative method approach, case studies. The Covid 19 case was recorded in the Tanah Kali Kedinding Village having the highest score compared to the other three villages in Kenjeran District, Surabaya City. To explain the phenomenon of the high number of Covid 19 cases in Kali Kedinding Village compared to the other three urban villages, secondary data collected from related agencies is used.

\section{Location}

This activity was carried out in Tanah Kali Kedinding Village, Kenjeran District, Surabaya City in June-July 2020, carried out by the ITATS (Institute of Technology Adhitama Surabaya) Environmental Engineering Deparment team consisting of students and accompanying lecturers.

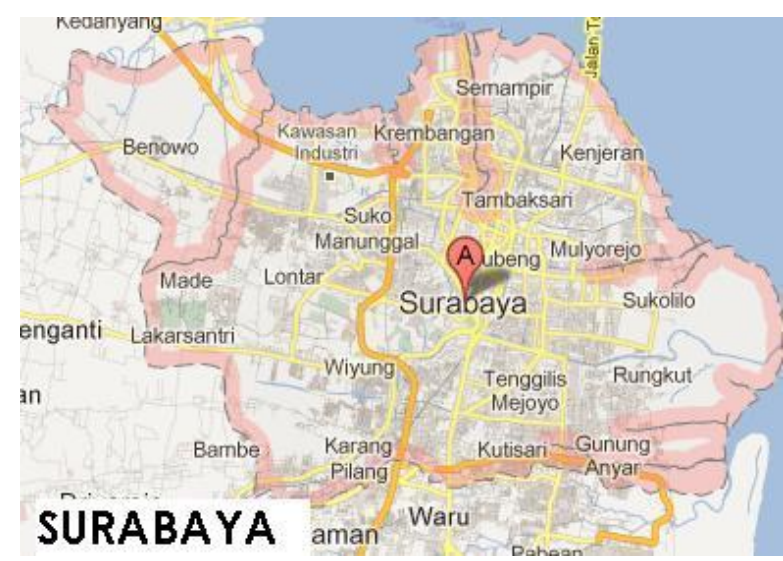

Figure 1. Kenjeran District is located in the northern part of Surabaya City

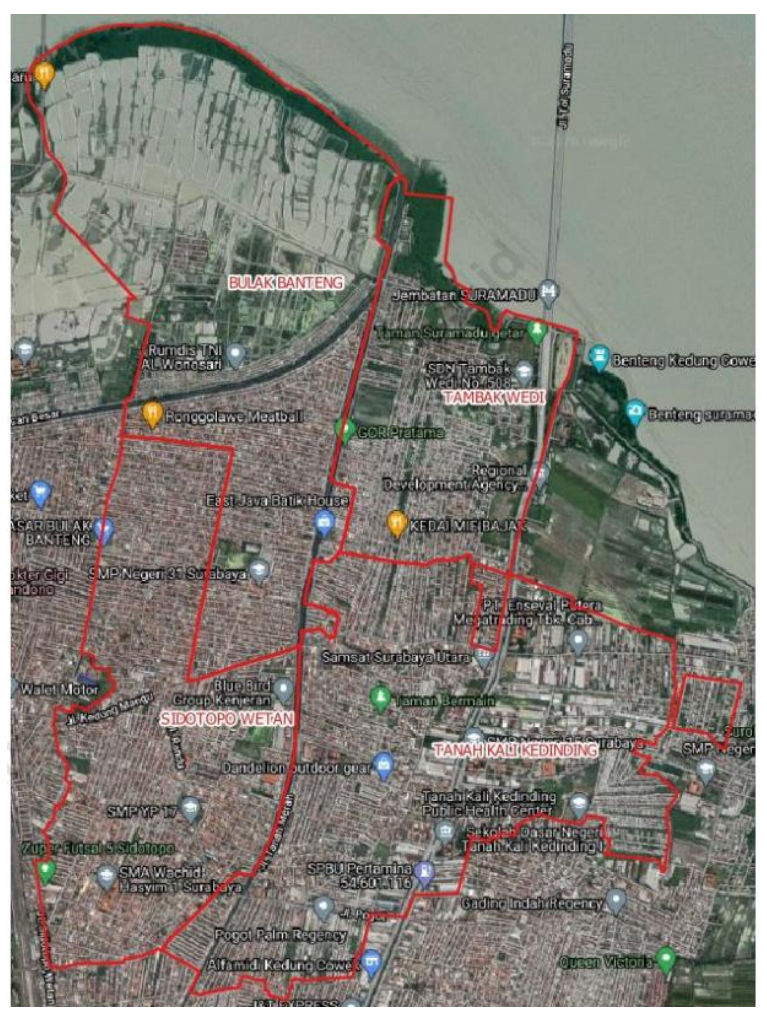

Figure 2. Kenjeran District, Surabaya City 


\section{Result and Discussion}

The general description of the population of Kenjeran District including density, educational background and employment, is presented in the following graph (Kenjeran District in Figures of the year 2020, 2020).

Table 1 Population Density

\begin{tabular}{lccc}
\hline \multicolumn{1}{c}{ Sub-District } & $\begin{array}{c}\text { Area } \\
\left(\mathrm{km}^{2}\right)\end{array}$ & $\begin{array}{c}\text { Total } \\
\text { population } \\
\text { (people) }\end{array}$ & $\begin{array}{c}\text { Density } \\
\left(\text { people } / \mathrm{km}^{2}\right)\end{array}$ \\
\hline Tanah Kali & 2.41 & 60,566 & 25,131 \\
$\begin{array}{l}\text { Kedinding } \\
\text { Sidotopo Wetan }\end{array}$ & 1.66 & 64,200 & 38,675 \\
Bulak Banteng & 2.67 & 36,517 & 13,677 \\
Tambak Wedi & 0.98 & 17,915 & 18,281 \\
\hline \multicolumn{1}{c}{ Total } & 7.72 & 179,198 & \\
\hline
\end{tabular}

Table 2 Average number of household

\begin{tabular}{lccc}
\hline Sub-District & $\begin{array}{c}\text { Total } \\
\text { population } \\
\text { (people) }\end{array}$ & $\begin{array}{c}\text { Household } \\
\text { number }\end{array}$ & $\begin{array}{c}\text { Average } \\
\text { population/ } \\
\text { house }\end{array}$ \\
\hline Tanah Kali & 60,566 & 17,629 & 3.4 \\
Kedinding & 64,200 & 18,373 & 3.5 \\
Sidotopo Wetan & 36,517 & 9,887 & 3.7 \\
Bulak Banteng & 17,915 & 5,050 & 3.5 \\
Tambak Wedi & 179,198 & 50,939 & \\
\hline \multicolumn{1}{c}{ Total } & & &
\end{tabular}

The population density of Kenjeran District is high (Table 1) with an average family member of 3-4 people per family (table 2). High population density causes crowds to easily occur in households and public facilities, such as means of transportation, markets, etc., making it difficult to maintain distance, thus facilitating the spread of the Covid 19 virus (Purnama \& Susanna, 2020)

Figure 3 shows that the majority of the population in Kenjeran District has a high school education background and below. The high number of people who do not / have not gone to school shows that the population is young, the age of children is quite large; this is also supported by Figure 4, which shows the high number of people who are not / not working. Therefore, clean and healthy living habits need to be carried out continuously by observing methods that are in accordance with the characteristics of the local community.

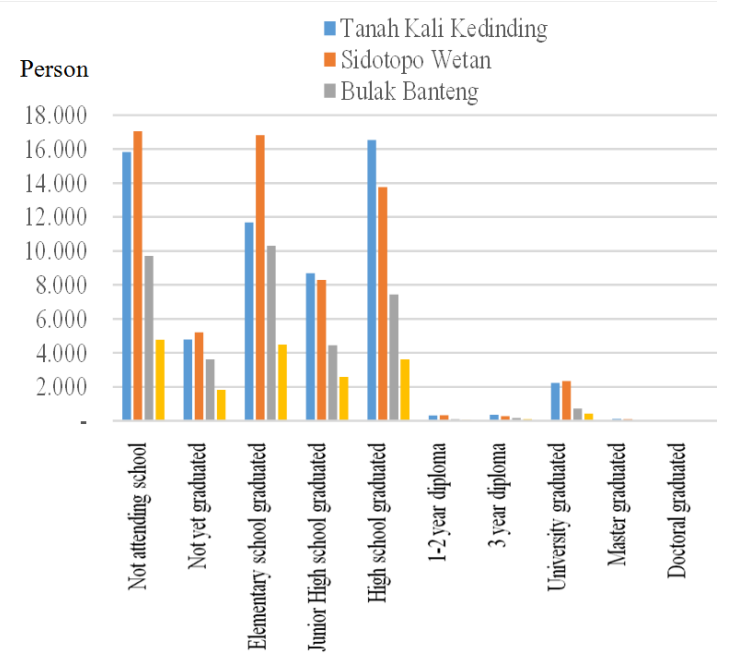

Figur 3 Educational background of residents of Kenjeran District

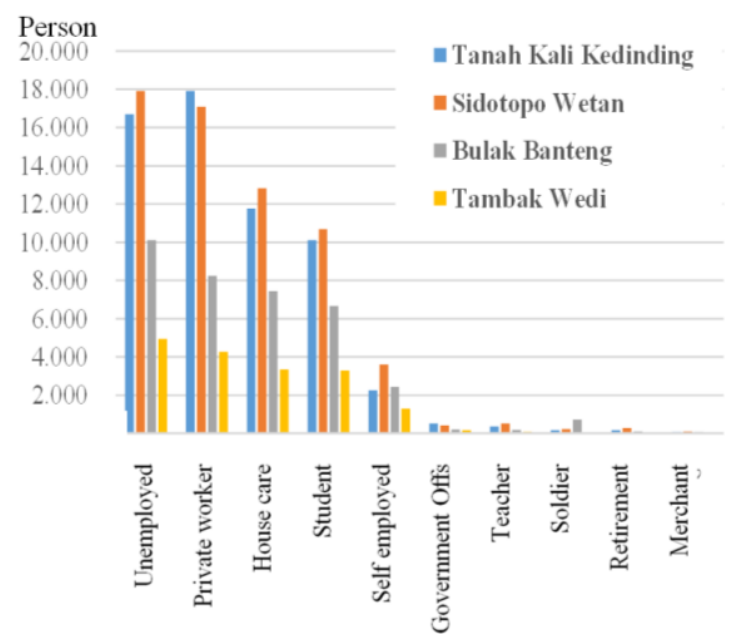

Figure 4 Type of occupation for residents of Kenjeran District

In June - July 2020 by paying attention to health protocols, the ITATS Environmental Engineering team collaborated with youth organizations accompanied by local community leaders to conduct education about clean and healthy living for themselves and the 
surrounding environment, as well as handing over assistance in the form of hand washing facilities, hand washing soap, as well as hand sanitizers to prevent the spread of Covid 19 in the region. The activity was carried out at Balai RW 01 of Tanah Kali Kedinding Village, Gang Arbei RT 06, and residents of RT 14 of Tanah Kali Kedinding Village.

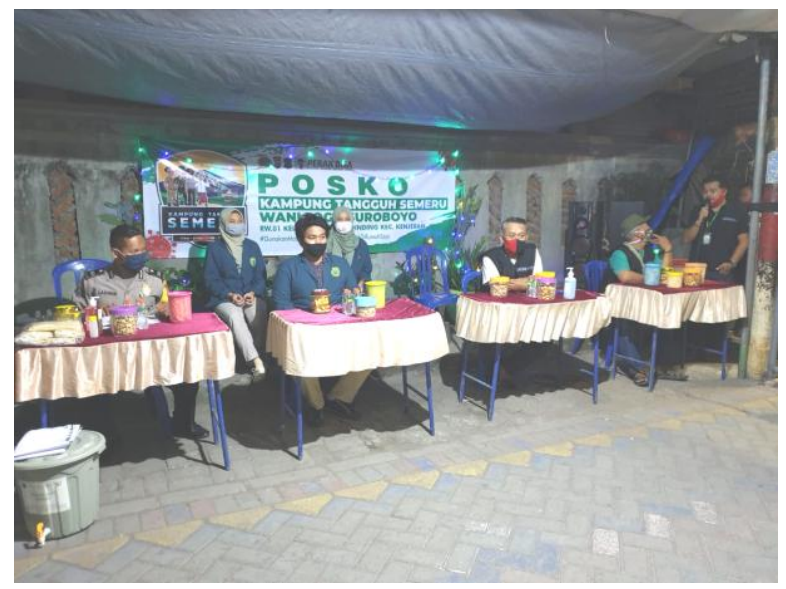

(a) Education on clean and healthy living

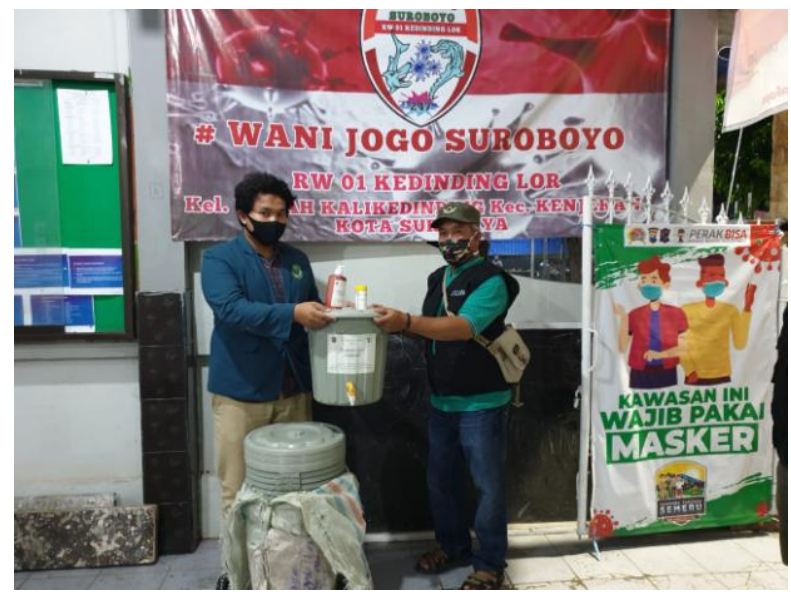

(b) Donation of soap hand washing tools

Figure 5 Activities in the Kelurahan Tanah Kali Kedinding

The decrease in the rate of confirmation of Covid 19 in Kenjeran District has occurred since September 2020, this means that the community has adapted to new habits during the pandemic by increasing awareness of maintaining cleanliness and health (Figure 6).
Figure 7 shows the highest addition of new cases occurred in Kelurahan Tanah Kali Kedinding from July to September 2020, after which new cases decreased in all sub-districts in Kenjeran District. In April - May 2020, the public still does not understand about the Covid 19 disease, while in June-September 2020 the community has gradually begun to adapt and apply the habit of wearing masks, washing hands and maintaining distance with more and more education through the media. This has an impact on the cumulative confirmation of Covid 19 cases (Figure 6) (Proverbs, 2020) (Bakhtiar et al., 2020).

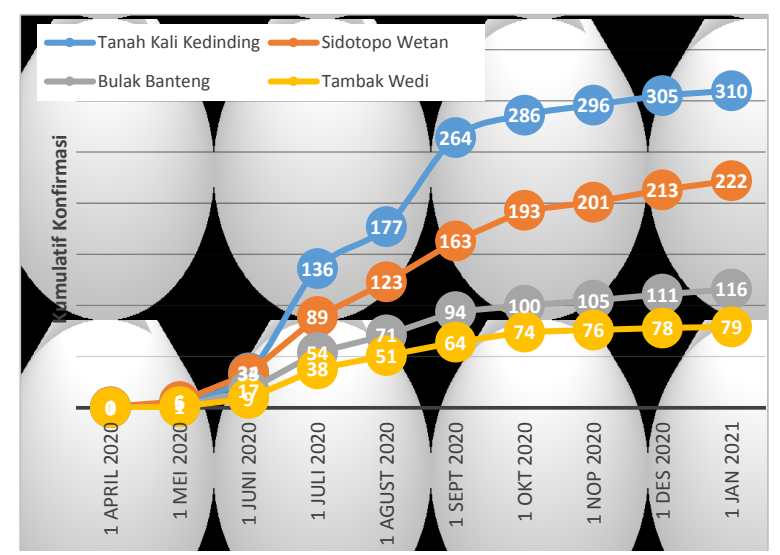

Figure 6. Cumulative confirmation of the Covid 19 case in Kenjeran District (https://lawancovid19.surabaya.go.id/visualisasi/graph)

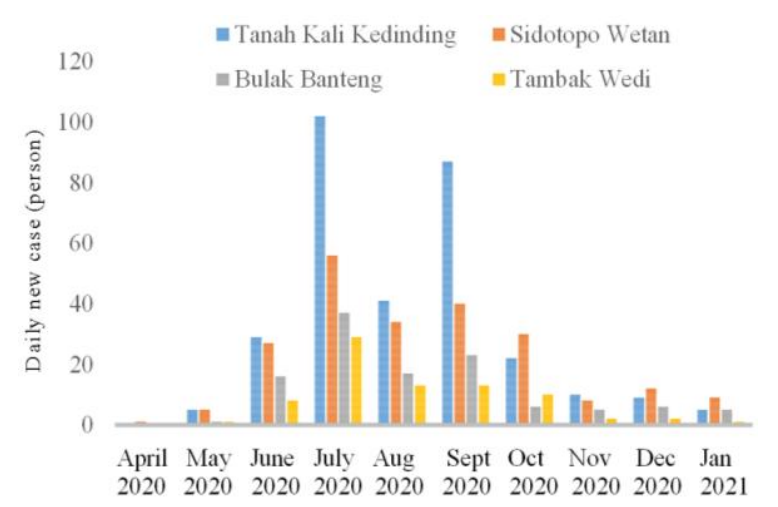

Figure 7. Addition of new Covid 19 cases in Kenjeran District (https://lawancovid19.surabaya.go.id/visualisasi/graph) 
Usually, it takes a long time to form a habit in society to adopt a new behavior. This happens especially if behavior change is required to be part of the adult community (Alfiah et.al., 2018). The formation of new habits is usually provided through youth education and into the primary school curriculum. One of the subjects related to this includes Environmental Education (Rachman et.al, 2015). However, in this community service activity, the rapid improvement of people awareness was obtained. It played an important role in slowering Covid 19 spreading in this area.

\section{Conclusion}

Everyone can play a role in preventing the spread of Covid 19 by adopting clean and healthy living habits. Education on clean and healthy living needs to be carried out. The awareness of the Kenjeran District community to live clean and healthy has helped reduce the rate of increase in confirmed cases of Covid 19.

The community service activities which are including assissanship and facilities donations show significant role in improving the awareness of the community to life cleaner and healthier.

\section{Acknowledgement}

Our gratitude goes to the ITATS Environmental Engineering students and lecturers who have jointly carried out this community service activity.

\section{References}

Alfiah, T., \& Yuliawati, E. (2018). Analisis Resiko Kesehatan Lingkungan Udara Ambien terhadap Pengguna Jalan dan Masyarakat sekita pada Ruas Ir. Sukarno Surabaya. INFOMATEK: Jurnal Informatika, Manajemen Dan Teknologi, 20(1), 27-34.

Amsal, A. (2020). The Water, Soap, Sanitation, and Handwashing Facilities are Associated with COVID-19 Transmission in 44 Countries.
Poltekita: Jurnal Ilmu Kesehatan, 14(1), 50-57. https://doi.org/10.33860/jik.v14i1.86

Bakhtiar, R., Hilda, H., Duma, K., \& Yudia, R. C. P. (2020). Relationship between understanding of COVID-19's infographics and the efforts to prevent COVID-19 transmission. Journal of Community Empowerment for Health, 3(2), 67. https://doi.org/10.22146/jcoemph.56749

Iriani, S. S., Manoy, J. T., Dinata, V. C., \& Ronaboyd, I. (2020). The Role of University in Empowerment of Clean Living for Anticipating the Spread of Covid-19 at East Java: Proceedings of the International Joint Conference on Arts and Humanities (IJCAH 2020). International Joint Conference on Arts and Humanities (IJCAH 2020), Surabaya, East Java, Indonesia. https://doi.org/10.2991/assehr.k.201201.232

Kecamatan Kenjeran Dalam Angka 2020. (2020). Badan Pusat Statistik Kota Surabaya. https://surabayakota.bps.go.id/publication/downl oad.html?nrbvfeve=ZDE1NGE4OWRmYTc3O Dg5YmRjOTA2NWMy\&xzmn=aHR0cHM6Ly 9zdXJhYmF5YWtvdGEuYnBzLmdvLmlkL3B1 YmxpY2F0aW9uLzIwMjAvMDkvMjgvZDE1N GE4OWRmYTc3ODg5YmRjOTA2NWMyL2tl Y2FtYXRhbi1rZW5qZXJhbi1kYWxhbS1hbmd rYS0yMDIwLmh0bWw\%3D\&twoadfnoarfeauf $=$ MjAyMS0wMi0yMCAyMTozMjozMg\%3D\% $3 \mathrm{D}$

Kementerian Kesehatan RI. (2011). Pedoman Pembinaan Perilaku Hidup Bersih dan Sehat (PHBS).

https://promkes.kemkes.go.id/download/jsg/files 13583Pedoman_umum_PHBS.pdf

Peraturan Menteri Kesehatan Republik Indonesia nomor: 2269/MENKES/PER/XI/2011 Pedoman pembinaan perilaku hidup bersih dan sehat (PHBS). (n.d.).

Purnama, S. G., \& Susanna, D. (2020). Hygiene and Sanitation Challenge for COVID-19 
Prevention in Indonesia. Kesmas: National Public Health Journal, 15(2). https://doi.org/10.21109/kesmas.v15i2.3932

Rachman, I., Toru, M., \& Yustiani, Y. (2015). Influence of Parent's Behavior to the Children Awareness on the Environmental Preservation. Journal Sampurasun :
Interdisciplinary Studies For Cultural Heritage, 1(1). doi:10.23969/sampurasun.v1i1.22

[Surabaya lawan covid-19]. (n.d.). https://lawancovid19.surabaya.go.id/visualisasi/graph. 